\begin{tabular}{|llll}
$\begin{array}{l}\text { Flash flood } \\
\text { Tropical storm } \\
\text { devastates labs } \\
\text { in Texas } \\
\text { p874 }\end{array}$ & $\begin{array}{l}\text { German jitters } \\
\text { tethics council } \\
\text { delays approval for } \\
\text { stem-cell research } \\
\text { p875 }\end{array}$ & $\begin{array}{l}\text { Pot looters } \\
\text { Archaeologists } \\
\text { express fears } \\
\text { over thieves } \\
\text { p876 }\end{array}$
\end{tabular}

\title{
Database of molecular probes set to boost chemical genetics
}

\section{David Adam}

A powerful open-access database that would link proteins to their role in cells and pinpoint their effects on whole organisms is being planned by the US National Cancer Institute (NCI).

Under the plans, the NCI would ask scientists around the world to deposit data on the effects of small chemical molecules on proteins, cell pathways and tissue formation. An additional important aspect would be the compilation of data on how such molecules affect an organism's phenotype - the observable characteristics that result from the expression of its genes.

The database has been dubbed 'ChemBank' by some of its supporters, who see it as a chemical version of GenBank, the online repository for genetic data.

A search of ChemBank for all known effects of a given molecule could reveal connections between previously unrelated biological functions. If a particular molecule that is known to bind a protein, for example, is also found to disrupt a metabolic pathway, this could show that the protein is directly involved in that pathway. The repository would effectively hold all the available data in the emerging field of 'chemical genetics' (see Nature 407, 282-284; 2000).

Plans for the database are at an early stage. But the NCI will take the first steps towards it later this year by establishing dedicated 'molecular targeting laboratories'. These labs will synthesize tens of thousands of small molecules and screen them for their biological effects. The information produced will be added to existing similar types of data to form the backbone of the database.

"This struck me as something that we really needed," says NCI director Richard Klausner. "If we're ever going to have an annotated database of molecular probes chemical entities that recognize and may or may not do things to gene products - then it's going to require a pretty systematic effort to characterize and develop those probes."

Although Klausner believes that such probes will ultimately be used in cancer treatment, he insists that the new scheme is "not a drug-discovery programme". Rather,

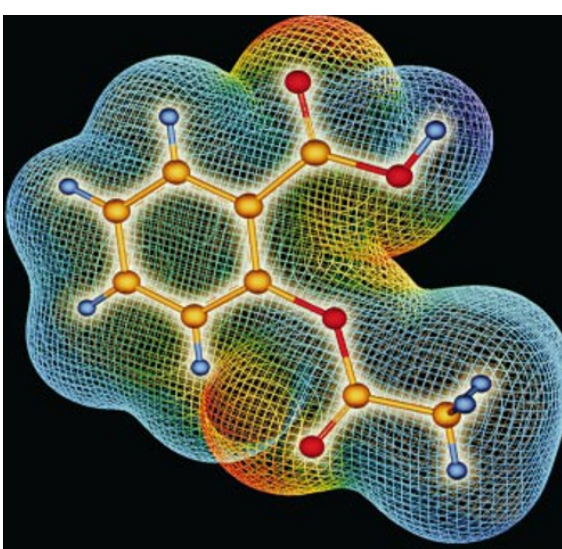

Shapes of the future: the proposed database may uncover new uses even for familiar aspirin.

it aims to compile a complete catalogue of the effects of molecular probes on gene products, pathways and phenotypes, he says.

The NCI is currently considering proposals from potential hosts and will announce its support support for one or more molecular targeting labs within a few months. Funding for the first year will be around $\$ 10$ million, and that will subsequently increase, says Klausner.

One candidate to host such a laboratory is Harvard University's Institute of Chemistry and Cell Biology. "It's a big, big undertaking and pretty speculative at the moment," says Stuart Schreiber, the institute's co-director. "But it could help us realize the full potential of chemical genetics." Existing collections of data on small molecules generally consist of information on protein binding and rarely include phenotypic effects, he notes. "Binding data by themselves don't illuminate biology."

Craig Crews, a cell biologist who works in chemical genetics at Yale University, says the database would be "extremely valuable". As well as revealing new aspects of cell biology, he adds, it will streamline efforts to relate research on new molecules to existing data. "Right now you have to be something of a detective to make those links," Crews says.

\section{Asthma study death spurs inquiry}

Paul Smaglik, Washington

The death this month of a woman taking part in an asthma study at Johns Hopkins University, Baltimore, has prompted a formal investigation by the US Office for Human Research Protections (OHRP).

The experiment, funded by the National Institutes of Health (NIH), was designed to study how lung function differs in asthmatic and healthy people. In an attempt to find out why the airways remain open when irritating chemicals are inhaled, healthy people were asked to inhale substances that affect these airways.

Some of the research subjects, who were paid about $\$ 60$ a visit up to a maximum of $\$ 365$, inhaled hexamethonium, which can temporarily paralyse some nerves in the airways. Those subjects, and others who had inhaled a saline-solution control, then took an asthma test.
The death at Johns Hopkins comes at a time when research using human subjects is under increased scrutiny in the United States. After the death in 1999 of a young man in a gene-therapy experiment at the University of Pennsylvania, the US government transferred responsibility for overseeing such research from the NIH's Office for Protection from Research Risks to the new OHRP, under the direct supervision of the US health secretary. Investigation of this latest death will provide the first major test of the new arrangement.

The exploratory focus of the asthma experiment has already attracted criticism. Vera Sharav, president of the New Yorkbased Citizens for Responsible Care \& Research, calls it a "fishing expedition" best reserved for animals, not people. "People should be protected from this kind of experiment," she says. 